Egyptian Journal of Aquatic Biology \& Fisheries

Zoology Department, Faculty of Science,

Ain Shams University, Cairo, Egypt.

ISSN $1110-6131$

Vol. 24(4): 155 - 167(2020)

www.ejabf.journals.ekb.eg

\title{
SOME REPRODUCTIVE ASPECTS OF THE COMMON SILVER BIDDY GERRES OYENA (FORSSKAL, 1775) FROM THE GULF OF SUEZ, RED SEA, EGYPT
}

\author{
Menna Allah A. Osman ${ }^{1}$; Azza A. A. El Ganainy ${ }^{2 *}$, Hafez H. M. Khouriba ${ }^{1}$; \\ Mervat M. Aly ${ }^{1}$
}

1. Faculty of Agriculture, Suez Canal University, Egypt.

2. National Institute of Oceanography and Fisheries, Egypt.

*Corresponding Author; azzaelgan@yahoo.com

\section{ARTICLE INFO}

Article History:

Received: June 12,2020

Accepted: July 2, 2020

Online: July 4, 2020

Keywords:

Sex ratio, common silver biddy

Spawning season, Length at maturity, Gerres oyena, Gulf of Suez.

\begin{abstract}
The common silver biddy Gerres oyena is one of the most commercial fish species in the Gulf of Suez. The reproductive characteristics of $G$. oyena were investigated in the Gulf of Suez during the period from 2015 to 2016. The overall sex ratio of males to females was estimated at 1: 2.1. Males predominated the small length groups from 10.5 to $13.5 \mathrm{~cm}$, while females dominated the larger lengths $>13 \mathrm{~cm}$. The monthly average values of gonad weight percentages and monthly different maturity stages showed that the species spawns during late spring with intensive spawning in May. The length at first sexual maturity was estimated at $13.5 \mathrm{~cm}$ for males and $14.1 \mathrm{~cm}$ for females which indicates that all individuals over two years of age were sexually mature. The results of this study can be used as a key figure for the conservation and maintenance of this commercially valuable stock in the Gulf of Suez.
\end{abstract}

\section{INTRODUCTION}

The success or failure of life of a fish in any environment largely depends on its spawning potential. Therefore information on spawning habits, spawning periodicities and spawning season is an essential pre-requisite to arrive at a better understanding of the animal regeneration of their stock and also are of great value in fishery predictions and formulations of management measures.

The Gerreidae, comprise eight genera and approximately 40 species commonly known as majorras, silver biddies or purse mouths, is found in most warm seas, most of them are seen is tropical region, a few are temperate species and frequently enter brackish or 
freshwater of estuaries and rivers (Randall, 1995; Nelson, 2006). They are small to medium sized fishes living is sandy shallows of tidal creeks, lagoons, coral reefs and some enter into freshwaters. Gerres oyena (Forsskal, 1775) is called the common silver biddy, it is widely distributed in all warm seas of Indopacific, from the east coast of Africa through Indomalayan Archipelago, South China Sea, Northern Australia and west Pacific islands (Woodland, 1984).

Despite the abundance as well as the economic and commercial importance of the common silver biddy Gerres oyena in the Gulf of Suez, they are one of the least investigated species in the region. Thus previous studies on reproduction and maturity of this species are scarce. El-Boray and El Gharabawy (1999) and El-Boray (2001) were the only studies dealt with reproductive biology of the species in the Suez Bay. Lamtane, Prata and Ndaro (2007) and Kanak and Tachihara (2008) studied the reproductive biology of Gerres oyena from Japan. This study aims to investigate some reproductive aspects including se ratio, development of maturity stages, spawning season and length at first maturity of the species in the Gulf of Suez.

\section{MATERIALS AND METHODS}

\section{Sampling:}

Monthly random samples (759 specimens ranging from 10.2 to $20.2 \mathrm{~cm}$ total length) of the common silver biddy Gerres oyena were collected from the commercial catches of the trawl fishery of the main landing site in the Gulf of Suez (Attacka harbor) during the period from September 2015 to June 2016. For each specimen, total length (distance from the tip of snot to the end of the caudal fin) was measured to the nearest millimeter (mm) and the total weight to nearest milligram (mg) was determined. Sex and maturity stages were determined microscopically and weight of the gonads $(\mathrm{GW})$ was recorded to the nearest $0.01 \mathrm{~g}$. Stages of maturity were classified as follows: I immature; II maturing; III developing; IV gravid; V running; and VI spent.

\section{Data analysis}

The sex ratio of the sampled population was analyzed monthly and according to the size intervals. It was determined as the percentage of males to females (M:F). Chi-square test at $\mathrm{P}<0.05$ significance level was computed according to Snedecor (1956). The spawning season, condition and development of the gonads were determined following the monthly changes of the gonadosomatic index (GSI), calculated according to Anderson and Gutreuter (1983) as:

$$
\mathrm{GSI}=100 \mathrm{GW} / \mathrm{TW}
$$

Where GW is the gonad weight and TW is the total fish weight.

The length at first sexual maturity (the length at which $50 \%$ of G. oyena reach the sexual maturity) was estimated by fitting the percentage maturity 
against mid lengths (King, 1995). Lm was estimated as the point on X-axis corresponding to $50 \%$ point on $\mathrm{Y}$-axis.

\section{RESULTS AND DISCUSSION}

\section{Sex Ratio:}

Sex ratio is the ratio of females to males in the stock, it reflect the reproduction potential of the fish. Comparing female to male ratio computed in relation to variation in length and during different periods of the year. In total dissected sample of G. oyena the sex ratio $\mathrm{M} / \mathrm{F}$ was $1: 2.1$. As for the total 513 specimens 165 individuals of them were males and 348 individuals were females. The monthly sex ratio is given in Table (1) and Figure (1). It can be seen that females dominated the catch during the peak of spawning season (May), such preponderance of one sex could be due to behavioral differences between the two sexes. Similar observations were also made by Kurup and Samuel (1991). The sex ratio in relation to mid length are given in Table (2) and Figure (2), Males predominated the small length groups from 10.5 to $13.5 \mathrm{~cm}$, while females dominated the larger lengths $>13 \mathrm{~cm}$. The chi-square value was $122.11(\mathrm{P}<.05)$, this value showed highly significant difference between both sexes.

Table 1. Monthly variations in sex ratio for G. oyena from the Gulf of Suez

\begin{tabular}{ccccccc}
\hline \multirow{2}{*}{ Month } & Total & \multicolumn{2}{c}{ Male } & \multicolumn{2}{c}{ Female } & ratio Sex \\
\cline { 2 - 6 } & No. & No. & $\%$ & No. & $\%$ & \\
\cline { 2 - 5 } Jan & 74 & 17 & 22.97 & 57 & 77.03 & $1: 3.4$ \\
Feb. & 49 & 16 & 32.65 & 33 & 67.35 & $1: 2.1$ \\
March & 49 & 13 & 26.53 & 36 & 73.47 & $1: 2.8$ \\
April & 50 & 8 & 16.00 & 42 & 84.00 & $1: 5.3$ \\
May & 39 & 4 & 10.26 & 35 & 89.74 & $1: 8.8$ \\
June & 48 & 22 & 45.83 & 26 & 54.17 & $1: 1.2$ \\
Sep. & 59 & 27 & 45.76 & 32 & 54.24 & $1: 1.2$ \\
Oct. & 62 & 31 & 50.00 & 31 & 50.00 & $1: 1.0$ \\
Nov. & 61 & 24 & 39.34 & 37 & 60.66 & $1: 1.5$ \\
Dec. & 22 & 3 & 13.64 & 19 & 86.36 & $1: 6.3$ \\
\hline
\end{tabular}




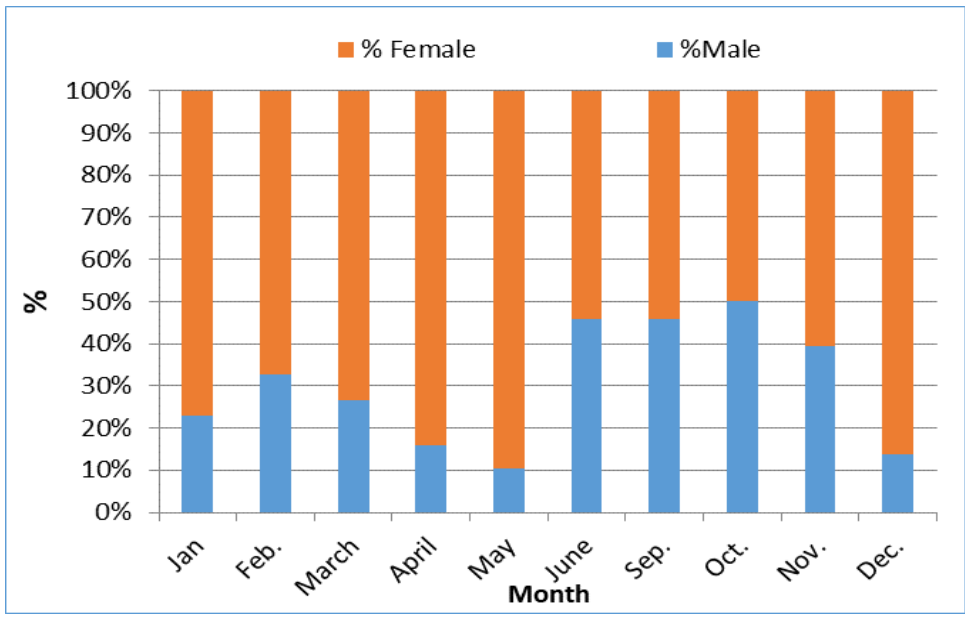

Figure 1. The monthly variations in sex ratio for G.oyena from the Gulf of Suez.

Table 2. Sex ratio of G. oyena in relation to the mid length.

\begin{tabular}{|c|c|c|c|c|c|c|}
\hline \multirow{3}{*}{$\begin{array}{c}\text { Mid } \\
\text { length }\end{array}$} & \multirow{3}{*}{$\begin{array}{c}\text { Total } \\
\text { No. }\end{array}$} & \multicolumn{2}{|c|}{ Male } & \multicolumn{2}{|c|}{ Female } & \multirow{2}{*}{ ratio Sex } \\
\hline & & & & & & \\
\hline & & & & & & \\
\hline 10.5 & 5 & 3 & 60.00 & 2 & 40.00 & $1: 0.7$ \\
\hline 11.5 & 43 & 24 & 55.81 & 19 & 44.19 & $1: 0.8$ \\
\hline 12.5 & 143 & 62 & 43.36 & 81 & 56.64 & $1: 1.3$ \\
\hline 13.5 & 150 & 50 & 33.33 & 100 & 66.67 & $1: 2.0$ \\
\hline 14.5 & 113 & 17 & 15.04 & 96 & 84.95 & $1: 5.6$ \\
\hline 15.5 & 43 & 6 & 13.95 & 37 & 86.05 & $1: 6.2$ \\
\hline 16.5 & 10 & 2 & 20.00 & 8 & 80.00 & $1: 4.0$ \\
\hline 17.5 & 6 & 3 & 50.00 & 3 & 50.00 & $1: 1$ \\
\hline 18.5 & 2 & 1 & 50.00 & 1 & 50.00 & $1: 1$ \\
\hline 20.2 & 1 & & & 1 & 100.00 & $0: 1$ \\
\hline Total & 513 & 165 & 32.16 & 438 & 67.84 & $1: 2.1$ \\
\hline
\end{tabular}




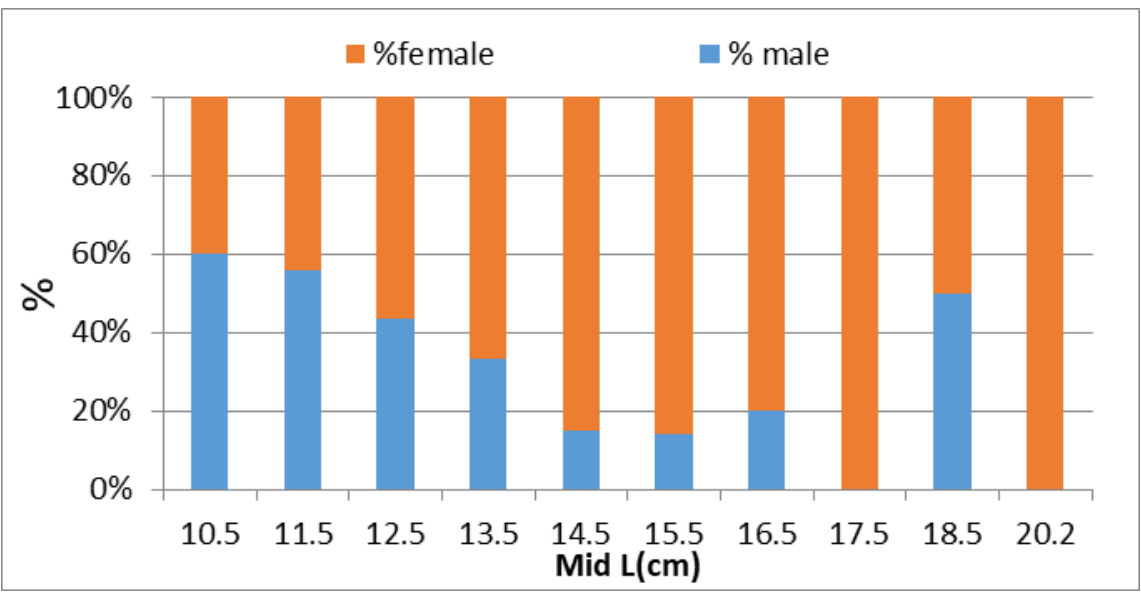

Fig. 2. Sex ratio of G. oyena in relation to the mid length.

\section{Maturity stages:}

Maturity stages represent the degree of ripeness of ovaries and testes. It is important to give indication for start and ending of the spawning activity. The conditions of the gonads G. oyena fish and their maturity stages (Table 3) were classified according to El Ganainy (2004) and Osman (2016) with slight modifications.

Table (3) Description of different maturity stages of $G$. oyena

\begin{tabular}{|c|c|c|}
\hline Maturity stage & Male & Female \\
\hline $\begin{array}{l}\text { Maturing } \\
\text { virgin stage } \\
\text { (2) }\end{array}$ & $\begin{array}{l}\text { Translucent redish-gray testes its } \\
\text { length about } \\
1 / 2 \text { the length of body cavity no } \\
\text { milt exuded by presser on it. }\end{array}$ & $\begin{array}{l}\text { Translucent red-redish gray ovary } \\
\text { with compact wall under } \\
\text { binocular microscope eggs can be } \\
\text { distinguished as polygonally } \\
\text { shaped. }\end{array}$ \\
\hline $\begin{array}{l}\text { Developing and } \\
\text { recovering ( } 3 \text { ) }\end{array}$ & $\begin{array}{l}\text { Opaque, white with blood } \\
\text { capillaries evident compact testes } \\
\text { with occupying about } 2 / 3 \text { the body } \\
\text { cavity. }\end{array}$ & $\begin{array}{l}\text { Opaque, redish-orange ovary, } \\
\text { thicker than in stage } 2 \text {, extending } \\
\text { about } 2 / 3 \text { length of body cavity. } \\
\text { Eggs are clearly recognizable. }\end{array}$ \\
\hline $\begin{array}{l}\text { Gravid stage، mature } \\
\text { stage (4) }\end{array}$ & $\begin{array}{l}\text { Opaque white testes with definite } \\
\text { length of } \\
2 / 3 \text { body length, very compact and } \\
\text { with pressure white milt runs out } \\
\text { slowly. }\end{array}$ & $\begin{array}{l}\text { Opaque orange ovary very } \\
\text { compact filling } 3 / 4 \text { body cavity, } \\
\text { immature، maturing and mature } \\
\text { ova present mature ova are more } \\
\text { numerous. }\end{array}$ \\
\hline $\begin{array}{l}\text { Running out or } \\
\text { spawning stage (5) }\end{array}$ & $\begin{array}{l}\text { Soft and creamy white testes milt } \\
\text { oozes out on pressing the gonad، } \\
\text { extended about } 3 / 4 \text { body cavity. }\end{array}$ & $\begin{array}{l}\text { Long and broad, ovary filling the } \\
\text { body cavity red or redish-yellow } \\
\text { in color' opaque mature ova } \\
\text { more numerous than maturing } \\
\text { ova. }\end{array}$ \\
\hline Fully spent stage (6) & $\begin{array}{l}\text { Very loose wall and rich blood } \\
\text { capillaries testes the color gray with } \\
\text { no milt comes out. }\end{array}$ & $\begin{array}{l}\text { Ovary with loose walls sometimes } \\
\text { with folds very much shorter and } \\
\text { bloody deep red in color. }\end{array}$ \\
\hline
\end{tabular}




\subsection{Monthly distribution of maturity stages:}

The results (Fig. 3) showed that, for males the ripe stage started from March to the end of August with the highest percent of ripening stage during July. The running stage started from April to September.

For females as shown in Figure (4), the ripening started from May to September and the running stage started from April to September with the highest value recorded during May. The spent stage value recorded from October to January and then the maturing and developing appeared during February to March. From these results it can be noticed that the spawning season extend from April to September, with the peak during May.

The variations in maturity stages and gonado-somatic index were used for discrimination between the different conditions of the gonads in the different periods, in order to identify the spawning season. The results indicated that $G$. oyena spawns during late spring early summer summer, with an intensive spawning in May and June, but the absence of data in the following months and the peak in September as well as the presence of high percentage of fish in full ripe and running maturity stages during September may lead to the assumption that the spawning season extends from May to September. Kanak and Tachihara (2008) reported that the spawning season of the common silver biddy Gerres oyena extends from March to September in Japan. These observation agree well with the observation of Rao (1970) and Patnaik (1971) who noticed that Gerres oyenas and Gerres. setifer spawn only once in a year in Pulicat and Chilka lakes respectively and the spawning period was a prolonged one.

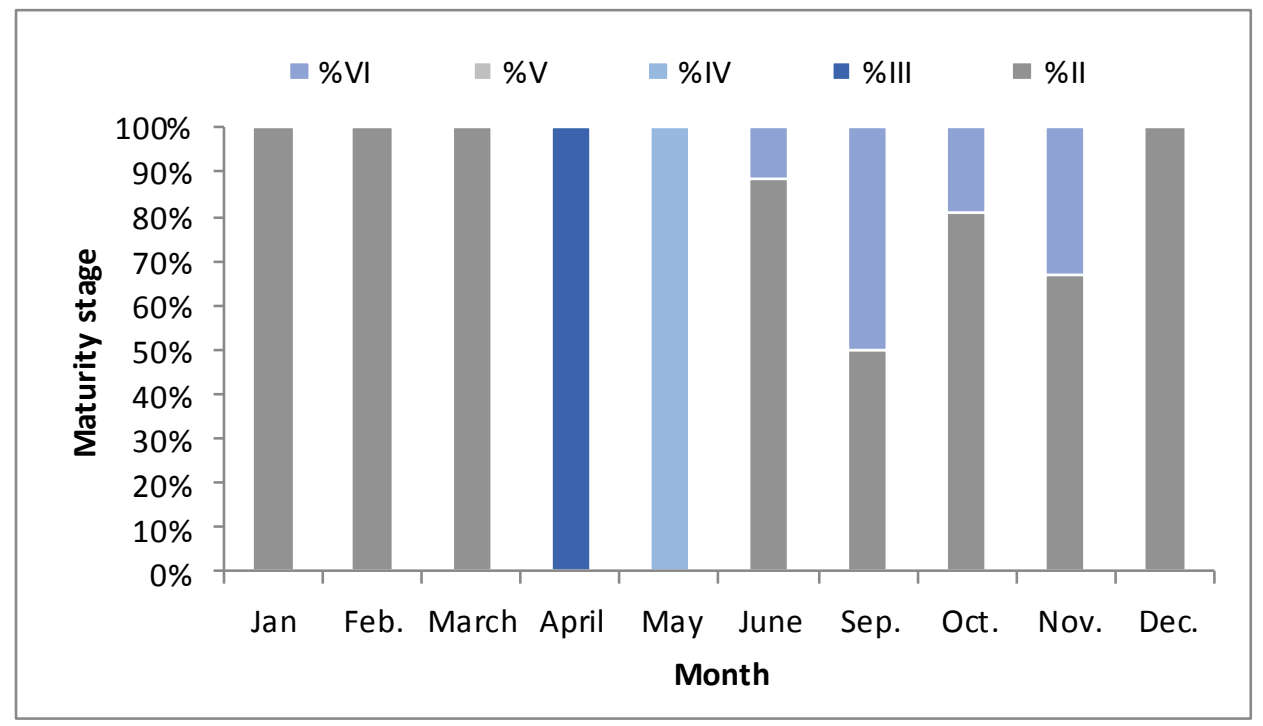

Fig. 3. Monthly distribution of maturity stages for male G. oyena from the Gulf of Suez during (2015-2016). 


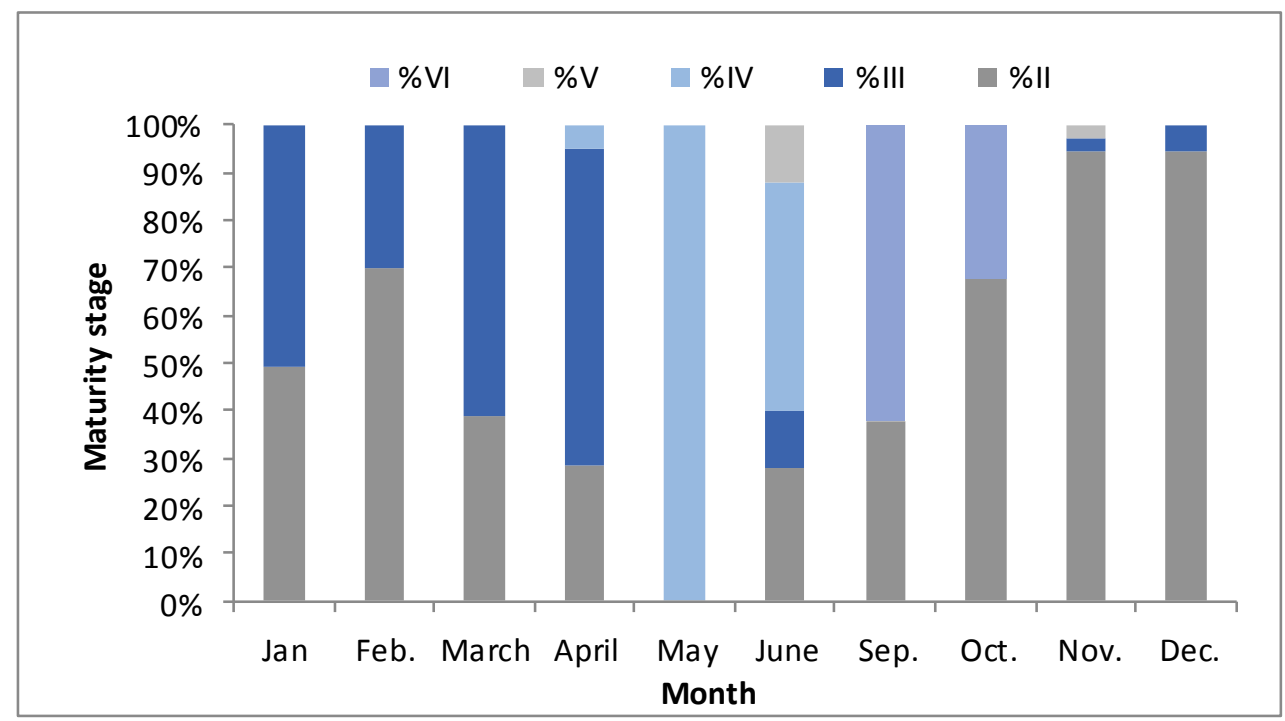

Fig. 4. Monthly distribution of maturity stages for female G. oyena from the Gulf of Suez during (2015-2016).

\section{Gonado-somatic index:}

The gonado-somatic index (GSI) was monthly investigated from September 2015 to June 2016 for both sexes (Fig 5). Females acquired higher average values of GSI than males in all months. The average value of GSI for males started to increase in April reached its peak in May $(8.474 \pm 5.6671)$, then GSI value decreased reaching its minimum value in November $(0.312 \pm 0.0719)$. For females, average value of GSI started to increase in May reaching its peak in June $(6.357 \pm 2.4573)$, then GSI value decreased sharply in November $(0.314 \pm 0.312)$. These results showed that, the spawning season of G. oyena was restricted to the period from April to September for both sexes with a peak in May and June.

These results are in agreement with that recorded by Kanak and Tachihara (2008) who studied the common silver biddy Gerres oyena from Okinawa Island of southern Japan and found that the temporal variation in the GSI reflected gonadal development from March to September and testes development occurred between March and August. Maximal development was observed in April and May in both sexes. El-Boray and El Gharabawy (1999) examined the histology of the ovaries of Gerres oyena from the Suez Bay and reported that the spawning season is long and extending from June to early September, while Lamtane, Prata and Ndaro (2007) found that G. oyena spawns throughout the year with two peaks: one in March and the other between October and December. Blaber and Blaber (1980) reported and observed recruitment of Gerres oyena only during the winter. 


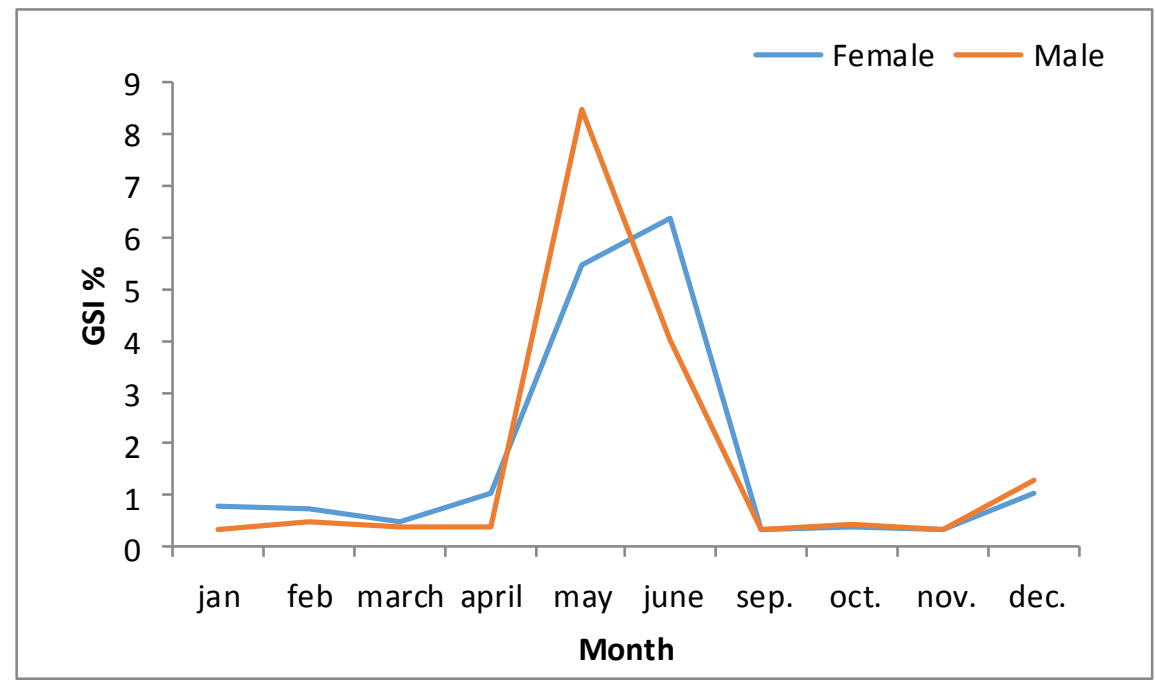

Fig. 5. Monthly variations on gonado-somatic index (GSI) of male and female G.oyena from the Gulf of Suez during (2015-2016)

\section{Length at first maturity:}

The size of fish when become mature is a very important parameter for management of species fisheries, according to length at first maturity we can indicate and determine the legal smallest size in the catch which don't cause over exploitation for the stoke (El Ganainy, 1997; El Etriby, et al., 2013).

Length at first sexual maturity $(\mathrm{Lm})$ is determined from the proportion frequency curve of developed mature males and females (stages III, IV, V) during April to September of 2015 (spawning season). The length at $50 \%$ maturity for male from the curve in Figure (6) was estimated as $13.5 \mathrm{~cm}$ and for female from the curve in Figure (7) was estimated as $14.1 \mathrm{~cm}$.

Yeeting (1990) estimated relatively high lengths at first maturity for the species in Tarawa Langoon, Kiribati $(19.0 \mathrm{~cm}$ for males and $22.0 \mathrm{~cm}$ for females). Lamtane, Prata and Ndaro (2007) recorded length at first maturity of the species in Bagamoyo coast close to our estimates $(12.8 \mathrm{~cm}$ and $13.9 \mathrm{~cm}$ of males and females respectively). On the other hand, Kanak and Tachihara (2008) recorded that the minimum standard length (SL) at sexual maturity was $89.7 \mathrm{~mm}$ for females and $81.4 \mathrm{~mm}$ for males and the size at which $50 \%$ of individuals were sexually mature was 104 and $92 \mathrm{~mm}$ SL in females and males, respectively. 


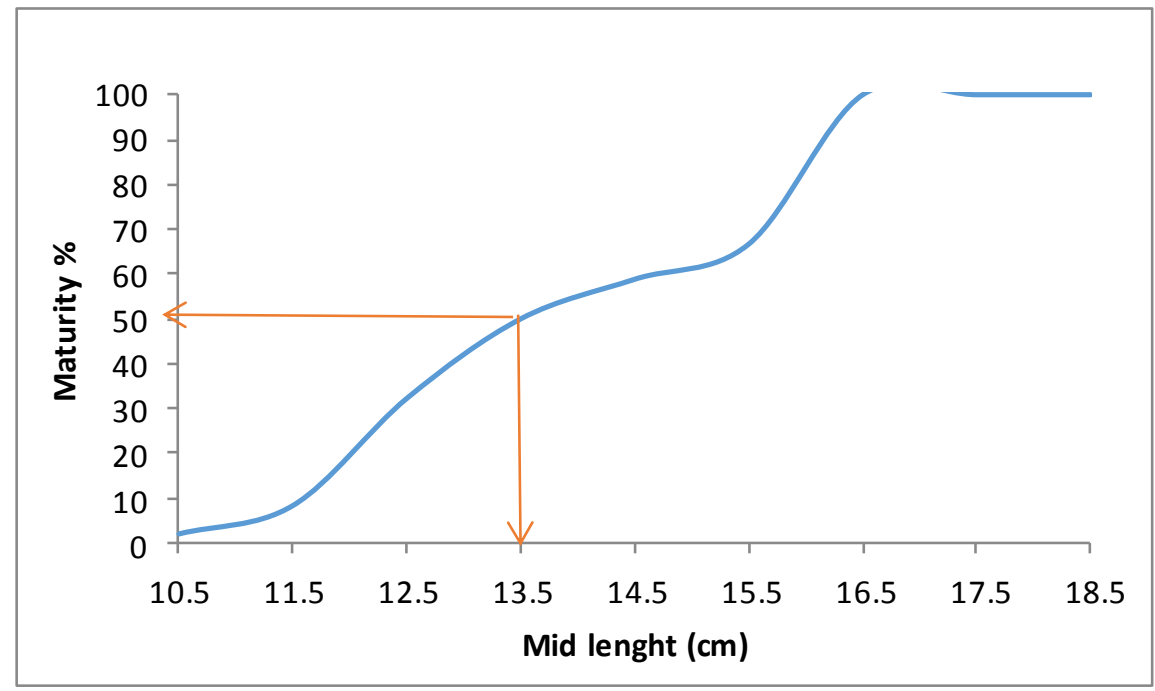

Fig. 6. Length at first sexual maturity for males of G. oyena from the Gulf of Suez.

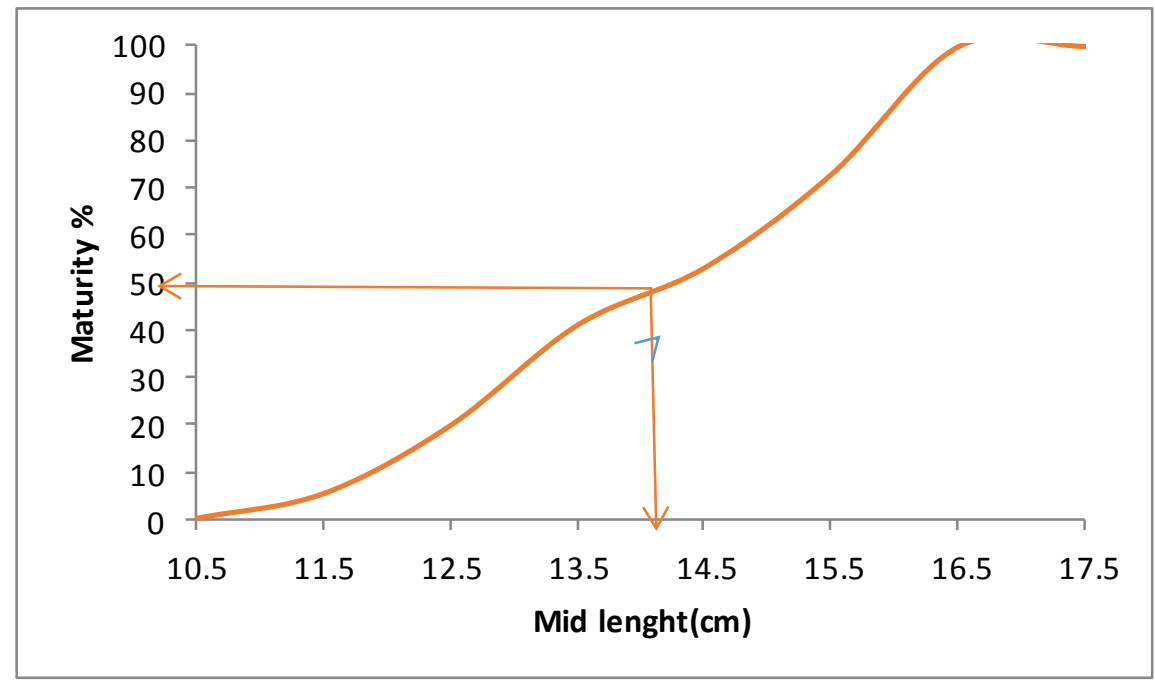

Fig. 7. Length at first sexual maturity for females of G. oyena from the Gulf of Suez.

\section{CONCLUSION}

The estimated length at first maturity in this study is larger than the length at first capture $(\mathrm{Lc}=12.59 \mathrm{~cm}$ ) estimated by Osman (2019). This reveals the intensive fishing pressure on young fishes, and the stock dynamics of this species would be seriously affected. The high vulnerability of juvenile fish to capture by different fishing gears would result in the reduction of the future yield of this species. Hence, the assurance of recruitment protection is likely the key figure for the conservation and maintenance of this commercially valuable stock. This may be achieved through the establishment of 
certain reserves in the Gulf of Suez to protect the spawning stock biomass, and then monitoring their effects as a management strategy (El-Ganainy and Sabrah, 2008).

\section{REFERENCES}

Anderson, R. and Gutreuter, S., (1983). Length, weight and associated structural indices. In: Fisheries Techniques. L. Nielsen, D. Johnson (eds). American Fish Soc., Bethesda, MD, pp. 283-300.

Blaber, S.J.M. and Blaber, T.G. (1980). Factors affecting the distribution of juvenile estuarine and inshore fish. J. Fish Bioi. 17: 143 - 162.

Cyrus D.P. and Blaber S.J.M. (1984). The reproductive biology of Gerres in Natal estuaries. J. Fish Biol. 24: 491-504.

El-Boray, K. F. M and El-Gharabawy, M. M. (1999). Histological characters of ovarian changes of Gerres oyena during the reproductive cycle in Suez Bay, Egypt. Egypt. J. Aquatic. Biol. \& Fish., 3(2): 115-129.

El Etriby, S.Gh.; El Ganainy, A.A.; Saber, M. A.; El Alwany, M. and El Bokhty, A. (2013). Age, growth and reproduction of the lizard fish Saurida undosquamis from the Gulf of Suez, Red Sea. Egypt. J. Aquat. Biol. \& Fish. 17(3): 25-34.

El-Ganainy, A. A. (2004). Biological characteristics and fishery assessment of the lizard fish Saurida undosquamis from the Red Sea, Egypt. Egypt. J. Aquat. Biol. \& Fish., 8(2):93-113.

El Ganainy, A.A. (1997). Population dynamics of Lizard fish (Synodontidae) from the Red Sea. Ph. D. thesis. Fac. Sci. Suez Canal Univ. Egypt. 267pp.

El-Ganainy, A. and Sabrah, M. M (2008). Biological Studies on the Filefish Setphanolepis Diaspros , Fraser-Brunner, 1940 ( Monacanthidae ) from the Gulf of Suez, Egypt. Egyptian Journal of Aquatic Biology and Fisheries 2013 Vol.17 Issue $1, \mathrm{pp}$

Kanak, K. and Tachihara, K. (2008). Reproductive biology of common silver biddy Gerres oyena in Okinawa Island of southern Japan. Fisheries Science 74: 265-275.

King, M. (1995). Fisheries biology, assessment and management. Fishing News Books, Oxford, England. 107-111.

Kurup B.M. and Samuel CT. (1991). Spawning biology of Gerres filamentosus Cuvier in the Cochin Estuary. Fish. Technol; 28: 19-24.

Lamtane, H.A.; Pratap, H.B. and Ndaro, S.M.G. (2007). Reproductive Biology of Gerres Oyena (Pisces: Gerreidae) Along the Bagamoyo Coast, Tanzania. Western Indian Ocean J. Mar. Sci. Vol. 6, No. 1, pp. 29-35.113-121.

Nelson, J. S. (2006). Fishes of the world, 4th edn. John Wiley \& Sons, Inc., Hoboken, New Jersey, USA, 601 pp.

Randall, J. E. (1995). Coastal fishes of Oman. University of Hawaii Press, Honolulu, 439 pp. 
Osman, M. A. (2019). Studies on the Fishery of Gerres oyena fish from the Gulf of Suez. M. Sc. Thesis, Faculty of Agriculture, Suez Canal University. 162 pp.

Patnaik, S. (1971). Observations on the fishery and biology of Chilka Jagili Gerres stiffer (Hamilton-Buchanan) inhabiting the coastal waters of Mangalore. J. Inland Fish Soci. India, 3: 25-43.

Rao AVP. (1970). Observations on some aspects of the biology of Gerres oyena (Forskal) with notes on the fishery of silver biddies of Pulicat Lake. J. Inland Fish. Soc. India; 2 :85-100.

Snedecor, G. W. (1956). Statistical methods applied to experiments in agricultural and biology, George W. Snedecor. The low state University. Press, U. S. A. 534p.

Woodland, D. J. (1984). Gerreidae. In: FAO species identification sheets for fishery purposes. Western Indian Ocean fishing area 51, Vol. 2. W. Fischer, G. Bianchi (Eds). FAO, Rome.

Yeeting, B.M. (1990). Notes on the Silver biddy Gerres oyena (Gerreidae) in Tarawa lagoon, Kiribati. Fishbyte 8.3: 8-10. 